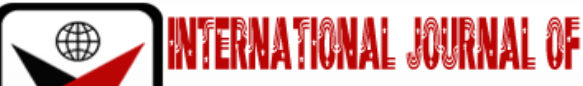

ISSN 2278-0211 (Online)

\section{The Role of Aqueous Extracts of Annona Muricata Linn in Regulating the Levels of Oxidative Markers in Caffeine-induced Brain Toxicity in Wistar Rats}

Nweze Sylvester Onuegbunam
Senior Lecturer, Department of Obstetrics and Gynaecology,
Nwagu State University of Science and Technology College of Medicine, Nigeria
Nwankw Malachy Nwaeze
Lecturer, Department of Pharmacology and Therapeutics,
Enugu State University of Science and Technology College of Medicine, Nigeria
Igwe Samuel Agina
Professor, Department of Pharmacology and Therapeutics,
Enugu State University of Science and Technology College of Medicine Parklane,
Okoye-Oli Ifeoma
Graduate Student, Department of Anatomy,
Enugu State University of Science and Technology College of Medicine, Nigeria
Esom Emmanuel A
Senior lecturer, Department of Anatomy,
Enugu State University of Science and Technology College of Medicine, Parklane, Nigeria

\begin{abstract}
:
This is an ethno pharmacology study in which the effect of leaves of soursop (Annona muricata Linn) was undertaken on caffeine -induced brain toxicity in wistar rats. Fourty-wister rats of both sexes weighing 90-250g were procured for the study. The rats were divided into 8 groups of 4 rats per gp, in which gp 1 served as the control, gps 2-7 served as the study or treatment gp while gp 8 received standard drug (lorazepam). All drug administration was by oral gavage and study lasted for 15 days after which the rats were sacrificed under chloroform anesthesia. The brain tissues were dissected and homogenized for estimation of superoxide dismutase (SOD) and malondialdehyde (MDA) levels and the rest for histological studies. Results showed that there were alterations in the histoarchitecture of the brain tissues i.e., distorted pyramidal cells with vacuolated cytoplasm, irregular pyramidal cells with darkly stained nuclei. Furthermore, Annona muricata demonstrated a significant difference in the oxidative stress makers (SOD and MDA) between the control and the drug treated groups. We conclude that Annona muricata leaves extract can efficaciously and effectively counter oxidative stress in caffeine -induced brain toxicity in rats.
\end{abstract}

Keywords: Caffeine brain toxicity, antioxidant, SOD, MDA

\section{Introduction}

Traditional African herbs contain many useful compounds that can be used in the treatment of many chronic diseases. Numerous reports suggest that traditional herbs have the potentials for preventing pathological outcome of some neurodegenerative diseases, cancers, drug- induced brain disorders etc., as most of the active principles of some useful drugs have been initially isolated from plants. Furthermore, most of the herbal drugs are a mixture of a number of plants or parts of the same plant ingredients whose cumulative effects increase their efficacy in curing diseases as well as reducing toxicity (Manomani et al, 1995). One such plant is Annona muricata Linn, called soursop due to the sweet and sour flavor of the large fruit, is a low and tropical fruit-bearing tree in the Annonaceae family, with long history of traditional use. It is an evergreen plant that is mostly distributed in tropical and subtropical regions of the world (Dalziel,1 955). This plant is a species of the family Annonaceae, order Magnolialies and division Magnoliophita (Farombis, 2003).

The genus Annona comprises over 70 species among which Annona muricata is the most widely used (Hutchison and Dalziel, 1963; Arbonier, 2004)

Soursop is native to tropical central and South America and the Caribbean but is now widely cultivated in tropical areas world-wide, including Southern Florida and Southeast Asia (Farombis, 2003).

Soursop is a slender, small and cold-intolerant tree, generally reaching heights of 4-6m, it flowers and bears fruit 3-5yrs after planting. The leaves are glossy, dark green, and generally evergreen, with a distinctive odour (Dalziel, 1955). 
Its fruits are the largest of the Annona species, $20-30 \mathrm{~cm}$ long often weighing $4.5 \mathrm{~kg}$. The fruits have green incredible skin, with many soft, curved spines, but the white juicy pulp is edible (Farombis, 2003). It has an aroma of pineapple but a sour or musky flavor, it is eaten fresh or used for making juice and other beverages, custards, etc., (Ekaluo et al, 2016).

Soursop, also referred to as graviola has numerous traditional medicinal uses in South America and the Caribbean, and has become nutritional medicinal supplement. The fruit, seeds, leave bark and roots have been used to treat intestinal parasites, coughs, asthma, bronchitis, liver ailments, inflammation, diabetes, hypertension, etc., (Ekaluo et al, 2016). The seeds are also insecticidal and the preparation from the leaves has been used to kill head-lice and bedbugs (Ekaluo et al, 2016). Further studies have shown that the extracts of graviola have antiviral, antiparasitic, antirheumatic, antiinflammatory and antihypertensive properties (Adewole and Ojewole, 2009). In addition to the health benefits of the Annonacee family, soursop also contains small amounts of neurotoxic alkaloids such as annonacin which appear to be linked to atypical parkinsonism and other neurological effects when consumed frequently and in large quantities ((Gyamfi et al, 2010)

Soursop leaves are rich in several compounds including proteins, calcium, fructose, vit A and B hence the leaves have excellent medicinal properties making them important ingredients in ethnomedicine. The leaves are employed in treating cystitis, diabetes, headaches and insomnia. Internal administration of the decoration exhibits antirheaumatic and neurologic effects while the boiled leaves are applied topically to treat abscess and rheumatism (Mishra et al, 2013, Ekaluo et al, 2016). The fruit is used as natural medicine for arthritic pain, neuralgia, arthritis, diarrhea, skin rashes, worm infestation and milk let down after delivery (Ekaulo et al, 2016).

Caffeine (1, 3, 7-trimethy1 xanthine) is the most commonly ingested pharmacologically active and psychoactive substance, found in beverages, in products containing cocoa and in some medications. Caffeine consumption alters circulating androgen levels in man (Ekaluo et al, 2016). It is a central nervous system stimulant (Graham, 2001), and once it reaches the blood stream, spreads throughout the entire system: respiratory, musculoskeletal, cardiovascular, renal and the central nervous system (Battram et al, 2008). Caffeine increases adrenergic discharge, elevating the heart rate, constricting blood vessel and thereby increasing the blood pressure (Battram et al, 2008). In the central nervous system, caffeine stimulates the release of excess serotonin in the brain which increases sympathetic activity and decreases neuronal inhibitor activity (Battram et al, 2008).

The purpose of this study is to explore the possibility of Annona muricata leaves extracts' effectiveness in countering caffeine- induced brain toxicity in the society which has reached an alarming rate. The orthodox treatment of this malady has not produced the desired results due to non-availability of drugs, poor economic presentation, treatment failures, etc. The resort to ethnomedicine becomes an alternate imperative using aqueous extracts of the leaves of soursop on caffeine-induced brain toxicity model in rats.

\section{Materials and Methods}

Fresh leaves of Annona muricata, harvested from the same tree were used for the study. The leaves were identified by the Taxonomist in the Botany Department of ESUT where a voucher specimen ESUT/BOT/168 is deposited in the herbarium. The fresh leaves of Annona muricata were washed with tap running water, dried in the laboratory at room temperature for two weeks before being ground into powder.

$500 \mathrm{~g}$ of the powdered Annona muricata sample was soaked in 2 litres of distilled water for $24 \mathrm{hr}$. The mixture was stirred every $8 \mathrm{hr}$ using sterile glass rod. The soaked sample was filtered using a Whatman No 1 filter paper at room temperature. The filtrate was concentrated using rotary evaporator at $40^{\circ} \mathrm{C}$, and finally dried in a water bath until the extract became completely solid. It was weighed and stored in refrigerator until required for the study and the yield was $65 \%$.

\subsection{Drugs}

The following drugs were used: Caffeine (Sigma Chemical Co, USA), Lorazepam, Wyeth USA, all were of reagent grade.

\section{Experimental Animals}

Forty adult albino rats of either sex, weighing 90-250 (mean 100.0 +_ 1.5g) were used for the study. The rats were procured from the Animal House of the Department of Pharmacology and Toxicology, University of Nigeria, Nsukka, Nigeria and quarantined for 2 weeks for acclimatization before use

The animals were housed in conventional wire mesh cages under controlled temperature condition of $28^{\circ} \mathrm{C}, 50 \%$ humidity and (12hour light/12hour dark) cycle. The rats had free access to water and were fed on standard livestock pellets from (Guinea feed Nig Ltd).

Experimental design:

The rats were weighed again and divided into 8 experimental groups of 4 rats each.

(a) Control

GP1- served as the control receiving only water and standard food pellets

GP2 - received $200 \mathrm{mg} / \mathrm{kg}$ caffeine per oral using cannula

(b) Prophylactic or protective effect of the extracts

GP 3- received $200 \mathrm{mg} / \mathrm{kg}$ extract $+200 \mathrm{mg} / \mathrm{kg}$ caffeine per oral using cannula

GP4- received $300 \mathrm{mg} / \mathrm{kg}$ extract $+200 \mathrm{mg} / \mathrm{kg}$ caffeine per oral using cannula

GP -5 received $400 \mathrm{mg} / \mathrm{kg}$ extract $+200 \mathrm{mg} / \mathrm{kg}$ caffeine per oral using cannula.

(c) Effects of the extract on rats pretreated with Caffein 
GP 6- received $200 \mathrm{mg} / \mathrm{kg}$ caffeine $+300 \mathrm{mg} / \mathrm{kg}$ extracts per oral using cannuala.

GP7 received $200 \mathrm{mg} / \mathrm{kg}$ caffeine $+300 \mathrm{mg} / \mathrm{kg}$ extracts per oral using cannula

GP- 8 received $200 \mathrm{mg} / \mathrm{kg}$ caffeine $+1 \mathrm{mg} / \mathrm{kg}$ lorazepam per oral using cannula

All the rats in the various cages had free access to food and water ad libitum and were kept for the next fifteen days.

On the $15^{\text {th }}$ day of the study the rats were weighed again and sacrificed under chloroform anesthesia. The brains were cut open and tissues for SOD (Super Oxide Distmutase) and MDA (Malondialdehyde) analysis were homogenized and preserved in sucrose solution.

\section{Results}

\begin{tabular}{|c|c|c|c|}
\hline Gp & $\begin{array}{c}\text { Superoxide dismutase } \\
\text { SOD g/mol }\end{array}$ & $\begin{array}{l}\text { Malondialdehyde } \\
\text { MDA g/mol }\end{array}$ & Remarks \\
\hline 1 & $479.1 \pm 3.3$ & $0.29 \pm 0.05$ & Only water and food \\
\hline 2 & $117.9 \pm 2.76$ & $12.66 \pm 0.07$ & Only $200 \mathrm{mg} / \mathrm{kg}$ caffeine \\
\hline 3 & $208.73 \pm 3.03$ & $2.44 \pm 0.07$ & $200 \mathrm{mg} / \mathrm{kg}$ extract and $200 \mathrm{mg} / \mathrm{kg}$ caffeine \\
\hline 4 & $313.87 \pm 3.07$ & $1.52 \pm 0.35$ & $300 \mathrm{mg} / \mathrm{kg}$ extract and $200 \mathrm{mg} / \mathrm{kg}$ caffeine \\
\hline 5 & $332.67 \pm 3.07$ & $0.91 \pm 0.07$ & $400 \mathrm{mg} / \mathrm{kg}$ extract and $200 \mathrm{mg} / \mathrm{kg}$ caffeine \\
\hline 6 & $170.47 \pm 4.26$ & $8.91 \pm 0.07$ & $200 \mathrm{mg} / \mathrm{kg}$ caffeine and $300 \mathrm{mg} / \mathrm{kg}$ extract \\
\hline 7 & $121.27 \pm 3.95$ & $10.16 \pm 0.14$ & $200 \mathrm{mg} / \mathrm{kg}$ caffeine and $300 \mathrm{mg} / \mathrm{kg}$ extract \\
\hline 8 & $191.83 \pm 3.10$ & $4.03 \pm 0.04$ & $\begin{array}{c}200 \mathrm{mg} / \mathrm{kg} \text { caffeine and } 1 \mathrm{mg} / \mathrm{kg} \text { lorazepan } \\
\text { standard drug }\end{array}$ \\
\hline & & & $\begin{array}{c}\text { Note: all the animals had free access to food } \\
\text { and water ad libitum drug administration } \\
\text { was per oral via canular. }\end{array}$ \\
\hline
\end{tabular}

Table 1: Levels of SOD and MDA in the Frontal Lobe of Caffeine Induced Toxicity in Rats

Caffeine alone caused a fall in SOD of $75.40 \%$ and a rise in the MDA of $4272.4 \%$ to cause toxic stress. In the same manner lorazepam produced a rise in SOD by $62.7 \%$ and fall in MDA of $68.17 \%$. On the other hand, Annona muricata produced similar results in caffeine-treated rats i.e., SOD increased by $44.59 \%$ and a reduction in MDA of $29.62 \%$.

MDA levels in rats treated with a constant dose of caffeine $(200 \mathrm{mg} / \mathrm{kg})$ and varying doses of Annona muricata $(200,300$, $400 \mathrm{mg} / \mathrm{kg}$ ) had fall in the levels of MDA: $2.44,1.32$ and $0.91 \mathrm{mg} / \mathrm{ml}$ respectively. When the level of caffeine is constant $(200 \mathrm{mg} / \mathrm{kg})$, the level of SOD falls in a progressive manner from 271 to $157 \mathrm{gm} / \mathrm{mol}$. (see Table 1).

\section{Discussion}

Caffeine (1,3,7 -trimethyl xanthine) is the most widely consumed stimulant drug in the world (Shannon, 2007). It is present in a variety of forms: medications, coffee, tea, soft drinks and chocolate. It is commonly used to keep awake and alert. It is technically a drug and the recommended daily intake for healthy adults is $400 \mathrm{mg}$, (Shannon, 2007). Caffeine is a fast acting stimulant that acts on the central nervous system to increase the blood pressure, heart rate and boost energy (Marx et al, 2010). Caffeine acts to increase the activity of reticular formation hence its ability to maintain wakefulness (Hitner and Nagle, 1994).

Antioxidants attack free radicals, waste products created when the body converts food into energy. Free radicals cause harmful chemical reaction that can damage cells in the body making it difficult for the body to fight infections. They also damage organs and tissues (Shannon, 2007)

In the present study, before caffeine administration superoxide dismutase (SOD) activity dropped by $75.4 \%$ while malondialdehyde, (MDA), activity increased by more than $4000 \%$ causing toxic stress. Superoxide dismutase (SOD) enzyme, acts as antioxidant and protects cellular components from being oxided by reactive oxygen species formed as a result of toxic stress. During increased levels of oxidative stress SOD concentration increased with the degree of stress conditions. SOD out-competes damaging reactions of superoxide thus protecting the cell from superoxide toxicity. The main reactions are with itself (dismutation) or with another biological radical such as nitric oxide.

Results showed that MDA contents of caffeine-induced toxicity were significantly higher than those of the control at the same time point, while the SOD activities were significantly lower than those of the control group. For the extracttreated group (Annona muricata), MDA contents were significantly reduced and SOD activities increased significantly in caffeine-induced toxicity.

MDA is the end product of lipid peroxidation, while SOD is a biologically active substance that could eliminate harmful substances generated during metabolic processes. Their changes indicated that Annona muricata administration could effectively counter oxidative stress in caffeine-induced brain toxicity in rats.

Lorazepan, a benzodiazepine acts on the limbic system to produce its effects i.e., increasing the SOD level by 62 . $71 \%$ and reducing the MDA level by $68.17 \%$ in the caffeine-treated rats. On the other hand, Annona muricata extract produced similar results in caffeine treated rats i.e., SOD increased by $44.59 \%$ and a reduction in MDA of $29.62 \%$. The difference between the effect of the standard drug lorazepam and the extract is not significant showing that Annona muricata extract might be acting on the limbic system. The limbic system is involved with emotional and behavioural response of the body associated with reward and punishment (Hitnar and Nagle, 1994), sexual behavior, anger, ruga, fear, anxiety and is important for mutual health. Lorazepam exerts a selective effect on the limbic system and is used for the treatment of certain behavioral and emotional disorders. 


\section{Conclusion}

Annona muricata Linn has a role in regulating the levels of oxidative markers in caffeine-induced brain toxicity in wistar rats which can be explored in human

\section{Competing Interests}

The authors declare that they have no competing interests.

\section{Funding}

This research was completely sponsored by the authors. There was no external funding to the research

\section{References}

i. Manomani S, Vishukiuathan VP, Subramanian S, Govindasamy S (1995): Biochemical Studies on the antiulcerogenic activity of cauvery 100, an ayuvve formulation in experimental ulcers, Indian Journal of Pharmacology 27:101 - 105

ii. Dalziel JM, (1955): The Useful plants of West Tropical Africa, The Crown Agents for the colonies, London, pp $449-445$.

iii. Farombi, EO (2003): Africa indigenous plants with chemotherapeutic potentials ard biotechnological approach to the production of bioactive prophylactic agents, Afr J Biotech 2:662 - 171.

iv. Adewole S0, and Ojewole J (2009): Protective effects of Annona muricata linn, (Announacea) leaf aqueous extract on serum lipid profile and oxidative stress in hepatocytes of streptozocin-treated diabetic rats Iranian J of Pharm Res-P6: 30 - 41

v. Battram DS, Dala F, Grahem TE, Sohemy AE and Thong FSL (2008): Does Caffeine alter muscle carbohydrate and fat metabolism during exercise? Coffee and Caffeine: The relationship with cancer, diabetes and cardiovascular disease, Canadian Soc for Clin Nutrition anual meeting, Applied Physio, Nutrition, and Metabolism 33:1311

vi. Ekaluo UB, Uno UU, Edu NE and Ekpo PB (2016): Effect of Trevo dietary Supplement on caffeine caused oxidative stress in albino rat models. The pharmaceutical and chemical Journal 3(2): 92 - 97.

vii. Graham TE (2001): Caffeine and exercise metabolism, endurance and performance. Sports Medicine 31(11): $785-807$

viii. Mishra S, Ahmed S, Kumar, N and Sharma BK (2013): Annona muricata (the cancer killer): A review Glob, J Pharm 2: 1613 - 1618

ix. Marx JA, Hockberge RS, Walls RM ed(2010): Rosen's Emergency Medicine: Concepts and Clinical Practice. Philadelphia, PA: Mosby/Elsevier.PP

x. Shannon MW. (2007): Theophylline and Caffeine. In: Shannon MW, Boron SW, Burns MJ eds. Haddad and Winchester's Clinical Management of Poisoning and Drug Overdose. $4^{\text {th }}$ ed. Philadelphia, PA: Samlars Elservier, Chap 65.

xi. Arbonier M (2004): Trees, shrubs and Lionas of West Africa Dry Zone. CIRAD. Margruf Publishers. GMBH. MNIN Cote D'ivorie 194.

xii. Hutchinson J, and Dalziel JM (1963): Flora of West Tropical Africa, Crown Agents for Overseas and Administration 4, Millbank London SW 3: 435 - 436.

xiii. Gyamfi K, Sarfo D, Nyarko B, Alaho E, Serfor-Armah Y and Ampomah A (2010): Assessment of element content in the fruit of graviola plant, Annona muricata from some selected communities in Ghana by instrumental neutron activation analysis. Elixir Food Science 41: 5671 - 5674.

xiv. Hitner, H and Nagle B (1994): Antipsychotic and Anti-anxiety Drugs, In Glencoe's: Basic Pharmacology, 4thed, Glenco - McGraw-Hill, NY, pp 157 - 158. 